\title{
Genetic Variability for Nitrogen Use Efficiency in Interspecific and Intergeneric Hybrids of Sugarcane
}

\author{
K. Mohanraj*, T. Manjunatha, C. Mahadevaiah, A. Suganya, \\ S. P. Adhini and P. Geetha \\ Department of Crop Improvement, ICAR-Sugarcane Breeding Institute, Coimbatore, India \\ *Corresponding author
}

\section{A B S T R A C T}

\section{Keywords}

Sugarcane,

Agronomic nitrogen use efficiency (AgNUE)

\section{Article Info}

Accepted:

15 December 2019

Available Online:

10 January 2020
Nitrogen is one of the most important mineral nutrients required for plant development especially for tillering and vegetative growth. Management of nitrogenous fertilizers poses a significant challenge in sugarcane cropping system as the efficiency of utilization of nitrogen is very poor. Improving the Nitrogen Use Efficiency (NUE) is imperative to achieve the maximum cane yield with less $\mathrm{N}$ inputs. In this study, 32diverse sugarcane pre-breeding genetic stocks were evaluated with two levels of nitrogen $\left(\mathrm{N}_{0}\right.$ and $\left.\mathrm{N}_{100}\right)$ for agronomic, juice quality, biomass traits and Agronomic Nitrogen Use Efficiency (AgNUE). Significant genetic variability was observed among levels of nitrogen and genotypes. Wider differences were observed between phenotypic coefficient of variability (PCV) and genotypic coefficient of variability(GCV) indicating the role of nitrogen levels $\left(\mathrm{N}_{0}\right.$ and $\left.\mathrm{N}_{100}\right)$ in trait expression. Maximum agronomic efficiency was observed for interspecific hybrids of Saccharum spontaneum (77.92 kg of dry biomass $/ \mathrm{kg}$ of nitrogen) followed by intergeneric hybrid derivatives of Erianthus procerus $(52.61 \mathrm{~kg}$ of dry biomass $/ \mathrm{kg}$ of nitrogen). The study also revealed the early generation hybrids of $\mathrm{S}$. spontaneum and E. procerus recorded maximum AgNUE could be the potential sources for developing nitrogen efficient varieties in sugarcane. Therefore, these genotypes further considered for utilization in crop improvement programmes for development of elite breeding pools for nitrogen use efficiency.

\section{Introduction}

Sugarcane is an important $\mathrm{C}_{4}$ crop cultivated in the tropics and subtropics for production of both sugar and bioenergy (Waclawovsky et al., 2010; Dias et al., 2011; Smithers, 2014; Leal et al., 2016). Globally, sugarcane is cultivated in an area of 26.52 mhawith a production of 1877.10 million tonnes of sugarcane and 172.36 million tonnes of sugar production during 2017-18. It is one of the most promising agricultural biomass sources and nearly one-third of biomass (leaves and tops)is suitable for sustainable energy production and economically viable for generating bioelectricity (Smithers, 2014). Nitrogen is the most limiting crop nutrition which is essential for getting desired crop 
yields. Excessive use of nitrogen and cultivation of nitrogen inefficient cultivars promotes global climatic changes as emission of nitrous oxide is evident from the soil (Sornpoon et al., 2013 and Carmo et al., 2013). Sugarcane being a high biomass producing crop, requires larger quantities of fertilizer nitrogen with split doses during various stages of crop growth. The amount of nitrogen applied to sugarcane varies with different agroclimatic regions and cultivation practices followed. In India, it varies between $150 \mathrm{kgs} / \mathrm{ha}$ in subtropical to $300 \mathrm{~kg} / \mathrm{ha}$ in tropical India with additional $25 \%$ of $\mathrm{N}$ in ratoon crops. However, more than 50 per cent of Nitrogen supplied to the crop is lost through evaporation (Prammanee et al., 1988 and Prasertsak, 2002).

It clearly shows that there is a need to develop nitrogen efficient sugarcane genotypes which not only contributes significantly for sustainable sugarcane production but also reduces cost of sugarcane cultivation. The genetic variability available for Nitrogen Use Efficiency (NUE) in the parental gene pool is a pre requisite for designing appropriate breeding strategies (Garnett et al., 2015). Evaluation of large diverse population for NUE revealed the existence of significant genetic variation for $\mathrm{N}$ utilization in many crops (Rice, Singh et al., 1998; Barley, Sinebo et al.,2004; wheat, Le Gouis et al., 2000; Sugarcane, Robinson et al., 2007)which could serve as an initial donors for different NUE traits. However, several authors reported that due to modern plan breeding, selection under optimal $\mathrm{N}$ would have eroded the useful variation especially below ground root traits (wheat, Siddique et al., 1990;lettuce, Johnson et al., 2000). In a review on genetic variation for NUE in modern wheat, Hawkesford (2017) concluded that limited variation in the modern cultivars and suggested for broader germplasm screening for major improvement for $\mathrm{N}$ uptake and utilization. There are only few published report on NUE in sugarcane and it is not known the extent of NUE in diverse base materials of different interspecific and intergeneric hybrids. In view of this, the present experiment was conducted with following objectives i) to find out the species/genera related to sugarcane contributes to NUE ii) to identify pre-breeding genetic stocks with high NUE to further utilize in the sugarcane breeding programme for developing cultivars with high NUE.

\section{Materials and Methods}

Genotypes, nitrogen rates, and experimental design

Thirty two sugarcane pre-breeding genetic stocks with broader genetic base derived from different interspecific and intergeneric hybrids were selected for the study. The list of clones along with its parentage are given in the table 1. The selected clones were a part of pre breeding programme at ICAR-Sugarcane Breeding Institute, Coimbatore, India.

The trial was conducted at East Chithirai Chavadi farm of ICAR-Sugarcane breeding Institute, Coimbatore, Tamil Nadu, India (110 N,770E, 427MSL altitude) during 2014-16. The soil analysis was done by sampling at $45 \mathrm{~cm}$ depth. The soil is a clay loam soil with a $\mathrm{PH}$ of 7.7 , EC of $0.38 \mathrm{ds} \mathrm{m}^{-1}$ and organic carbon of 0.55 . The soil is medium in $\mathrm{N}$ with $228.57 \mathrm{kgha}^{-1} \mathrm{a}$ and low in $\mathrm{P}\left(27.30 \mathrm{~kg} \mathrm{ha}^{-1}\right)$ and high in $\mathrm{K}\left(718.06 \mathrm{kgha}^{-1}\right)$.

The clones were planted in two rows of $6 \mathrm{~m}$ length with an inter row spacing of $0.9 \mathrm{~m}$. All the recommended agronomic practices except nitrogen fertilization were followed to raise good crop. Phosphorus was applied as basal and Nitrogen and Potassium were applied in two splits i.e 45 and 90DAP. Atrazine was applied as a pre emergence herbicide at 3 DAP to control broad leaved weeds. The 
experiment was laid out in a split plot design with two levels of Nitrogen (no Nitrogen designated as $\mathrm{N}_{0}$ and recommended dose of Nitrogen $\left(280 \mathrm{kgha}^{-1}\right)$ designated as $\mathrm{N}_{100}$.

\section{Data collection}

The following data viz., number of tillers ('000/ha at 120 days), stalk height at harvest (360 days), number of stalks ('000/ha at 360 days), stalk diameter (cm) and single stalk weight $(\mathrm{kg})$ at harvest, fresh and dry biomass yield $\left(\mathrm{tha}^{-1}\right)$ were recorded in each plot and in each replication. Five stalks were cut and crushed in a crusher and the extracted juice was used to estimate juice quality parameters viz., juice brix $\%$, sucrose $\%$, commercial cane sugar $\%$, purity $\%$, extraction $\%$ ). The fibre content $(\%)$ was estimated as detailed in Mohanraj and Nair (2014).Agronomic nitrogen use efficiency (AgNUE) defined as 'cultivar produces large quantity of harvestable biomass per unit of nitrogen supplied was estimated as described by Good et al., (2004).

\section{AgNUE}

Dry biomass under - Dry biomass under N 100 N0

Quantity of Nitrogen applied

\section{Statistical analysis}

Statistical analysis was performed for split plot design as described in Gomez and Gomez (1984) and total variability partitioned into variability due to nitrogen, genotypes and their interaction effects. The total variability due to genotypes further portioned into five categories (Kempthorne, 1957) viz., variability due to commercial clones (Co canes), interspecific hybrids of S. spontaneum (ISH) and intergeneric hybrid derivatives with $E$. arundinaceus (IGEA), backcross derivatives of E. procerus (IGEP) and intergeneric hybrid derivatives of sugarcane and sorghum (IGSS). Genotypic and phenotypic coefficient of variance, heritability (broad sense), and genetic advance as percent mean (GA) were estimated as described by Burton and deVane (1953) and Johnson et al., (1955).

\section{Results and Discussion}

\section{Analysis of variance and genetic variability parameters}

Analysis of variance revealed the presence of significant variation between two levels of nitrogen $\left(\mathrm{N}_{0}\right.$ and $\left.\mathrm{N}_{100}\right)$ and among genotypes for all the traits studied. Further, partitioning of total genetic variability into mean sum of square due to Co canes and ISH had shown significant genetic variation for all the traits except no. of tillers. IGEP had shown significant genetic variation for most of the traits except for stalk diameter and single stalk weight whereas IGSS recorded significant mean sum of squares only for quality related traits viz., sucrose (\%), purity (\%), CCS (\%) and fibre content (\%).

Genetic variability parameters such as phenotypic coefficient of variability (PCV), genotypic coefficient of variability $(\mathrm{GCV})$, heritability $\left(\mathrm{h}^{2}\right)$ and genetic advance (GA) as per cent mean for $\mathrm{N}_{0}$ and $\mathrm{N}_{100}$ is presented in table 2.Higher range, GCV and PCV for most of agronomic and biomass attributing traits was recorded in $\mathrm{N}_{100}$ and for juice quality parameters in $\mathrm{N}_{0}$. Wider differences were observed between GCV and PCV indicating the role of nitrogen levels $\left(\mathrm{N}_{0}\right.$ and $\left.\mathrm{N}_{100}\right)$ in trait expression. Stalk diameter $(\mathrm{cm})$, single stalk weight (kgs), number of stalks, juice brix $\%$, sucrose $\%$, purity $\%, \mathrm{CCS} \%$, juice extraction \%, fibre content (\%) showed relatively high heritability and stalk height $(\mathrm{cm})$ showed relatively moderate heritability under both levels of nitrogen. However, tiller number, fresh and dry biomass yield $\left(\right.$ tha $\left.^{-1}\right)$ 
showed relatively higher heritability of 0.71 , $0.69,0.72$ under $\mathrm{N}_{100}$ and low heritability of $0.21,0.31$ and 0.36 under $\mathrm{N}_{0}$ respectively.

\section{Performance of agronomic traits at $\mathrm{N}_{0}$ and} $\mathbf{N}_{100}$ levels

Agronomic traits viz.,no. of tillers, no. of stalks, stalk diameter, single stalk weight, juice quality traits such as juice extraction (\%) and biomass attributing traits viz., fresh biomass yield and dry biomass yield recorded significantly high yield in $\mathrm{N}_{100}$. Juice quality parameters such as brix $\%$, sucrose $\%$, juice purity \%, CCS (\%), fibre(\%) and dry matter (\%) recorded significantly higher mean under $\mathrm{N}_{0}$.

AgNUE was estimated to assess the genotypes for accumulation of biomass per unit of nitrogen application. The mean AgNUE was $41.24 \mathrm{~kg}$ of dry biomass per $\mathrm{kg}$ of nitrogen supplied.

Maximum agronomic efficiency was observed for ISH $(77.92 \mathrm{~kg}$ of dry biomass $/ \mathrm{kg}$ of nitrogen) followed by IGEP (52.61 kg of dry biomass $/ \mathrm{kg}$ of nitrogen), IGSS (40.18 $\mathrm{kg}$ of dry biomass/kg of nitrogen), IGEA $(30.88 \mathrm{~kg}$ of dry biomass $/ \mathrm{kg}$ of nitrogen) and the lowest agronomic efficiency was observed in Co canes $(23.09 \mathrm{~kg}$ of dry biomass/kg of nitrogen) (Table 3).

Sugarcane is high biomass producing crop used for both generation of sugar and bioenergy and other industrial use products through usage of bagasse and trashes (Dias et al., 2011; Furlan et al., 2013; Smithers, 2014; Leal et al., 2016). It is a high nitrogen demanding cropand efficient nitrogen management could able to improve sustainable sugarcane production. Excessive applications of nitrogen negatively impact the environment in sugarcane (Thorburn et al., 2017) and emission of greenhouse gases such as nitrous oxide $\left(\mathrm{N}_{2} \mathrm{O}\right)$ is evident from sugarcane fields (Signor et al., 2013; Sornpoon et al., 2013; Carmo et al., 2013). Excessive and indiscriminate usage of nitrogen causes global climatic change and emission due to agriculture is the third largest contributor to global greenhouse gases (Gelbert, 2012).

Global warming induced carbon fertilization with improved nitrogen use efficiency projected to increase in $24-31 \%$ increase in global agricultural $\mathrm{N}_{2} \mathrm{O}$ emissions by $2040-$ 2050 (Kanter, 2016).Heavy fertilizer loads contaminates the aquatic environments like lakes, rivers, oceans with water soluble nitrates causes ecological disorders like dead zones and damages aquatic life diversity (Good et al., 2004). Contamination of drinking water with nitrogen causes methemoglobinemia or blue baby syndrome (Knobeloch et al., 2000).

Therefore, careful and effective crop management through agronomic practices and deployment of nitrogen use efficient genotypes could able to minimize the negative impact on environment, and development of nitrogen use efficient sugarcane cultivars through breeding, variety selection and genetic modification has gained the greater importance(Wood et al., 2010).

Set of thirty two sugarcane clones consisting of commercial canes and prebred genetic stocks derived from interspecific and intergeneric hybrids showed significant mean sum of squares and relatively higher values of range, GCV, PCV for most of the traits under both $\mathrm{N}_{0}$ and $\mathrm{N}_{100}$ indicating the presence of significant variability among genotypes. Moderate PCV, GA with moderate high heritability observed for most of the traits including dry biomass under $\mathrm{N}_{0}$ suggesting that family/pedigree selection in large population (Roy, 2000) suitable for trait selection under nitrogen deficient condition. 
Table.1 Details of prebred genetic stocks used in the study

\begin{tabular}{|c|c|c|c|}
\hline Genotypes & Clone & Parentage & Salient Features \\
\hline G1 & Co 07017 & PIR 83-327 x Co 86011 & Commercial cane \\
\hline G2 & Co 06021 & Co 7201 x 97-257 & Commercial cane \\
\hline G3 & Co 07001 & Co 86011 x PIO 90-188 & Commercial cane \\
\hline G4 & Co 93009 & Co 678 x Co 775 & Commercial cane \\
\hline G5 & $\mathrm{CoC} 671$ & Co 775 x Q63 & Commercial cane \\
\hline G6 & Co 94019 & Co 7201 x Co 62175 & Commercial cane \\
\hline G7 & Co 94012 & Somaclone of CoC 671 & Commercial cane \\
\hline G8 & Co 95020 & Co 7407 x (CP 44101 x NG 7794) & Commercial cane \\
\hline G9 & Co 06002 & Co $85002 \times$ OH 44 & Commercial cane \\
\hline G10 & Co 07004 & Co 85002 x 96-77 & Commercial cane \\
\hline G11 & ISH 04-2097 & Co $8371(2 n=108) \times$ SH $216(2 n=72)$ & Interspecific hybrids of S.spontaneum \\
\hline G12 & ISH 479 & BO $130(2 n=110) \times$ IND $82-228(2 n=40)$ & Interspecific hybrids of S.spontaneum \\
\hline G13 & ISH1757 & Co $86249(2 n=108) \times$ SES $590(2 n=64)$ & Interspecific hybrids of S.spontaneum \\
\hline G14 & ISH732 & Co $1148(2 n=114) \times$ IND 82-319 $(2 n=56)$ & Interspecific hybrids of S.spontaneum \\
\hline G15 & ISH1875B & Co $89029(2 n=110) \times$ IND $84-394(2 n=112)$ & Interspecific hybrids of S.spontaneum \\
\hline G16 & ISH04-941 & Co $83712 n=108) \times$ IND $84-415(2 n=80)$ & Interspecific hybrids of S.spontaneum \\
\hline G17 & GU 07-3488 & GU04(22)RE560 x Co 775 & $\mathrm{BC} 1$ of $E$. arundinaceus \\
\hline G18 & GU 07-5317 & GU (50)RE-16 X CoS 510 & $\mathrm{BC} 1$ of $E$. arundinaceus \\
\hline G19 & GU 04(72) COE-1 & CoC 671 x IK 76-91 & IGH of E. arundinaceus \\
\hline G20 & GU 07-2276 & GU 04 (50) RE-9 X CoH 70 & $\mathrm{BC} 1$ of $E$. arundinaceus \\
\hline G21 & CYM 12-509 & CYM 10-601xCoT 8201 & $\begin{array}{c}\text { Fourth generation hybrids of } \\
\text { S.spontaneum } x \text { E. arundinaceus with } \\
\text { sugarcane. }\end{array}$ \\
\hline G22 & CYM 12-450 & CYM 10-601xCoT 8201 & $\begin{array}{c}\text { Fourth generation hybrids of } \\
\text { S.spontaneum } x \text { E. arundinaceus with } \\
\text { sugarcane. }\end{array}$ \\
\hline G23 & CYM 12-447 & CYM 10-601xCoT 8201 & $\begin{array}{c}\text { Fourth generation hybrids of } \\
\text { S.spontaneum } x \text { E. arundinaceus with } \\
\text { sugarcane. }\end{array}$ \\
\hline G24 & CYM 12-456 & CYM 10-601xCoT 8201 & $\begin{array}{l}\text { Fourth generation hybrids of } \\
\text { S.spontaneum } x \text { E. arundinaceus with } \\
\text { sugarcane. }\end{array}$ \\
\hline G25 & CYM 12-476 & CYM 10-601xCoT 8201 & $\begin{array}{c}\text { Fourth generation hybrids of } \\
\text { S.spontaneum } x \text { E. arundinaceus with } \\
\text { sugarcane. }\end{array}$ \\
\hline G26 & GU $12-25$ & GU04(28)EO-2 x Co 06027 & BC1 progeny of $E$. procerus \\
\hline G27 & GU 12-35 & GU04(28)EO-2 x Co 06027 & $\mathrm{BC} 1$ progenyof $E$. procerus \\
\hline G28 & GU $12-27$ & GU04(28)EO-2 x Co 06027 & $\mathrm{BC} 1$ progenyof $E$. procerus \\
\hline G29 & GU $12-38$ & GU04(28)EO-2 x Co 06027 & $\mathrm{BC} 1$ progenyof $E$. procerus \\
\hline G30 & GU $12-60$ & GU04(28)EO-2 self & Self-progenyof $E$. procerus \\
\hline G31 & GU $12-12$ & SSH $27 \times$ Co 94008 & BC 1of Saccharum-Sorghum hybrid \\
\hline G32 & GU 07-5622 & SSH-1 x CoC 8001 & BC 1of Sorghum- Saccharum hybrid \\
\hline
\end{tabular}


Table.2 Estimates of genetic variability parameters for traits associated with agronomic use efficiency of nitrogen under $\mathrm{N}_{0}$ and $\mathrm{N}_{100}$ condition

\begin{tabular}{|c|c|c|c|c|c|c|c|c|}
\hline \multirow[t]{2}{*}{ Traits } & \multicolumn{2}{|c|}{ PCV } & \multicolumn{2}{|c|}{ GCV } & \multicolumn{2}{|c|}{ Heritability (BS) } & \multicolumn{2}{|c|}{ GAM } \\
\hline & NO & N100 & No & N100 & NO & N100 & No & N100 \\
\hline No. of tillers & 31.96 & 35.85 & 14.72 & 30.17 & 0.21 & 0.71 & 13.97 & 52.31 \\
\hline Stalk height (cm) & 15.58 & 10.31 & 10.81 & 5.92 & 0.48 & 0.33 & 15.46 & 7.00 \\
\hline Stalk diameter $(\mathrm{cm})$ & 16.44 & 16.24 & 14.23 & 14.07 & 0.75 & 0.75 & 25.37 & 25.11 \\
\hline Single stalk weight (kg) & 37.79 & 33.27 & 32.00 & 28.61 & 0.72 & 0.74 & 55.81 & 50.70 \\
\hline Number of stalks & 36.73 & 42.29 & 29.61 & 39.11 & 0.65 & 0.86 & 49.16 & 74.52 \\
\hline Juice brix (\%) & 17.75 & 19.77 & 19.41 & 20.94 & 0.84 & 0.89 & 33.42 & 38.46 \\
\hline Sucrose $(\%)$ & 28.89 & 33.60 & 26.70 & 31.83 & 0.85 & 0.90 & 50.85 & 62.12 \\
\hline Purity (\%) & 15.13 & 18.91 & 14.21 & 18.18 & 0.88 & 0.92 & 27.49 & 35.99 \\
\hline $\operatorname{CCS}(\%)$ & 33.76 & 40.47 & 31.28 & 38.34 & 0.86 & 0.90 & 59.71 & 74.81 \\
\hline Extraction (\%) & 14.06 & 13.65 & 12.88 & 13.20 & 0.84 & 0.93 & 24.31 & 26.28 \\
\hline Fibre $(\%)$ & 19.18 & 23.46 & 18.84 & 23.25 & 0.96 & 0.98 & 38.11 & 47.45 \\
\hline Dry Matter (\%) & 7.17 & 10.26 & 6.11 & 9.67 & 0.73 & 0.89 & 10.74 & 18.78 \\
\hline Fresh biomass yield (t/ha) & 37.85 & 37.10 & 20.98 & 30.75 & 0.31 & 0.69 & 23.96 & 52.51 \\
\hline Dry biomass yield (t/ha) & 37.52 & 34.06 & 22.58 & 28.92 & 0.36 & 0.72 & 28.01 & 50.60 \\
\hline
\end{tabular}


Table.3 Mean performances of Co canes, ISH and IGH clones derived from E. arundinaceus, E. procerus and Sorghum for traits associated with agronomic use efficiency of nitrogen under $\mathrm{N}_{0}$ and $\mathrm{N}_{100}$ condition

\begin{tabular}{|c|c|c|c|c|c|c|c|c|c|c|c|c|}
\hline \multirow[t]{3}{*}{ Traits } & \multirow{2}{*}{\multicolumn{2}{|c|}{ Nitrogen Levels }} & \multicolumn{10}{|c|}{ Genotypes } \\
\hline & & & \multicolumn{2}{|c|}{ 'Co' canes } & \multicolumn{2}{|c|}{ ISH } & \multicolumn{2}{|c|}{ IGEA } & \multicolumn{2}{|c|}{ IGEP } & \multicolumn{2}{|c|}{ IGSS } \\
\hline & No & N100 & No & N100 & No & N100 & No & N100 & No & N100 & No & N100 \\
\hline No. of tillers & $133.80 * *$ & $148.55 * *$ & 116.67 & 113.80 & $174.07 * *$ & $216.67 * *$ & 123.46 & 125.62 & 131.67 & 158.33 & $150.46 * *$ & $196.76 * *$ \\
\hline Stalk height (cm) & $226.64 * *$ & $247.50 * *$ & $212.50 * *$ & $243.50 * *$ & $221.25 * *$ & $260.83 * *$ & 238.61 & 239.44 & $222.50 *$ & $248.00 *$ & 270.00 & 262.50 \\
\hline Stalkdiameter (cm) & $2.37 * *$ & $2.41 * *$ & 2.52 & 2.61 & 1.87 & 2.01 & 2.57 & 2.60 & 2.25 & 2.19 & $2.48^{*}$ & $2.30^{*}$ \\
\hline Single stalk weight (kg) & $0.75^{* *}$ & $0.88 * *$ & $0.82 *$ & $1.02 *$ & $0.44 *$ & $0.65^{*}$ & $0.92 * *$ & $0.94 * *$ & 0.60 & 0.71 & 0.97 & 0.95 \\
\hline Number of stalks & $103.04 * *$ & $122.45 * *$ & 80.46 & 84.44 & $152.78 * *$ & $195.68 * *$ & $90.74 *$ & $106.28 *$ & $101.30 * *$ & $124.44 * *$ & $126.39 * *$ & $160.65 * *$ \\
\hline Juice brix (\%) & $17.90 * *$ & $16.57 * *$ & $20.75^{*}$ & $19.67 *$ & $13.03 * *$ & $11.55^{* *}$ & $18.51 * *$ & $16.63 * *$ & $17.50^{*}$ & $16.54 *$ & 16.49 & 15.99 \\
\hline Sucrose $(\%)$ & $15.30 * *$ & $13.65 * *$ & $18.96^{*}$ & $17.75^{*}$ & $8.96 * *$ & $6.62 * *$ & $16.12 * *$ & $13.86 * *$ & 14.65 & 13.70 & 13.89 & 13.11 \\
\hline Purity (\%) & $83.22 * *$ & $79.50 * *$ & 91.17 & 89.87 & $64.75 * *$ & $54.46 * *$ & $86.44 * *$ & $82.89 * *$ & 83.41 & 81.85 & 83.92 & 81.56 \\
\hline $\operatorname{CCS}(\%)$ & $10.41 * *$ & $9.11 * *$ & $13.31 *$ & $12.40 *$ & $5.36 * *$ & $3.40 * *$ & $11.07 * *$ & $9.31 * *$ & 9.86 & 9.17 & 9.38 & 8.72 \\
\hline Extraction (\%) & $45.96^{* *}$ & $47.96 * *$ & $47.64 * *$ & $51.02 * *$ & $38.26 * *$ & $42.03 * *$ & $48.80 * *$ & $51.41 * *$ & $45.04 * *$ & $42.60 * *$ & $50.21 *$ & $48.39 *$ \\
\hline Fibre $(\%)$ & $18.85^{* *}$ & $17.79 * *$ & $16.98 * *$ & $15.71 * *$ & $23.75 * *$ & $21.66^{* *}$ & $16.88^{* *}$ & $15.85 * *$ & 20.17 & 20.67 & $19.05 * *$ & $18.12 * *$ \\
\hline Dry Matter (\%) & $33.46 * *$ & $31.49 * *$ & $34.22 * *$ & $32.31 * *$ & $33.70 * *$ & $30.73^{* *}$ & $32.28 * *$ & $29.86 * *$ & $34.17 * *$ & $33.77 * *$ & $32.40 *$ & $31.22^{*}$ \\
\hline $\begin{array}{l}\text { Fresh biomass yield } \\
\text { (t/ha) }\end{array}$ & $108.04 * *$ & $144.15 * *$ & 93.44 & 114.99 & $107.25 * *$ & $188.13 * *$ & 116.69 & 139.43 & $97.26 * *$ & $130.02 * *$ & $171.51 * *$ & $214.52 * *$ \\
\hline Dry biomass yield (t/ha) & $35.00 * *$ & $46.54 * *$ & $31.18 *$ & $37.65^{*}$ & $35.96 * *$ & $57.78 * *$ & $36.09 *$ & $44.73^{*}$ & $31.23 * *$ & $45.97 * *$ & $55.65^{* *}$ & $66.90 * *$ \\
\hline
\end{tabular}

* Significant at $5 \%$ level, ** significant at $1 \%$ level 


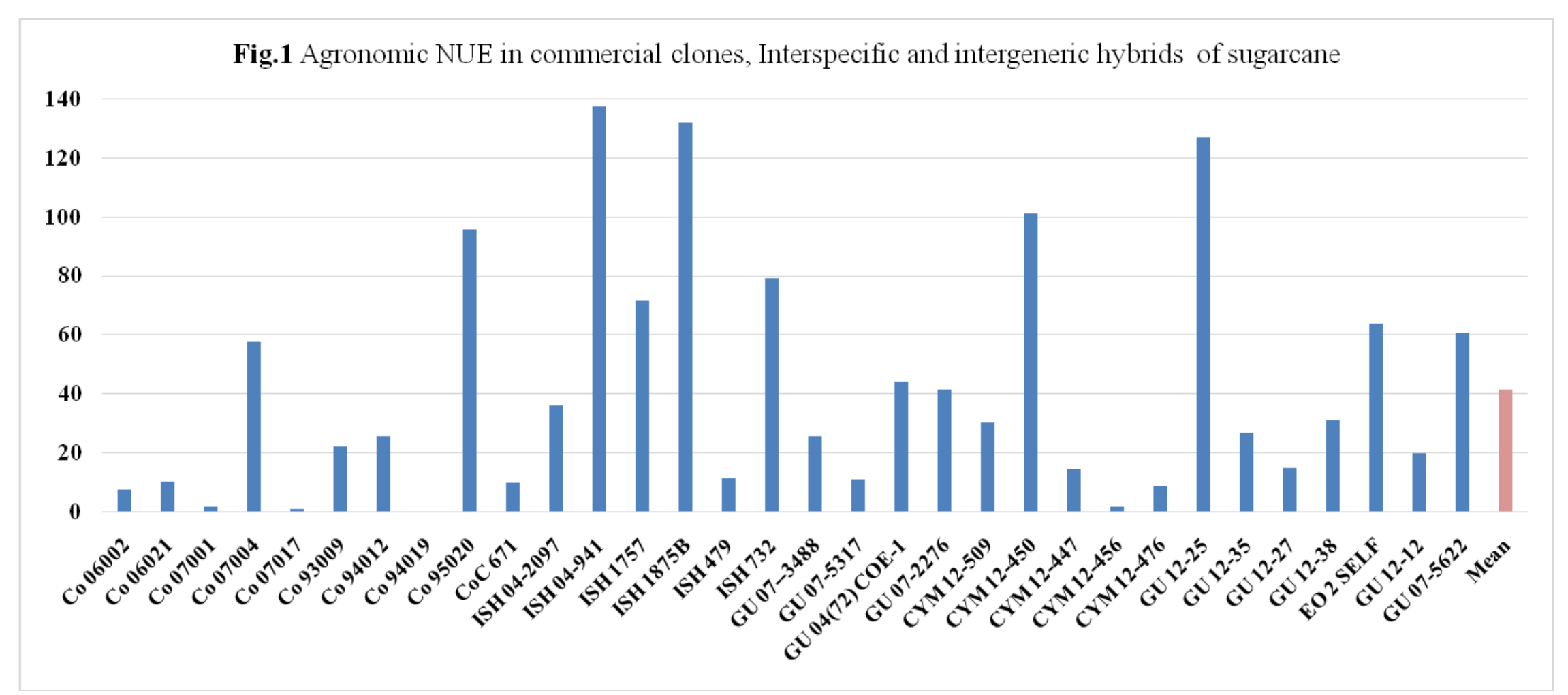


Gascho et al., (1986) reported that nitrogen use efficiency of sugarcane can be enhanced by selection under low $\mathrm{N}$ condition inferred based on quantum of nitrogen accumulated in different varieties in low nitrogen condition.

Agronomic traits and biomass attributing traits (fresh and dry biomass yield) recorded significantly higher mean in $\mathrm{N}_{100}$ and juice quality parameters (brix \%, sucrose $\%$, CCS $\%$ ), fibre $\%$ and dry matter $\%$ recorded significantly higher mean in $\mathrm{N}_{0}$. Similar reports of nitrogen deficient condition enhancing the accumulation of sucrose was reported in sugarcane cultivars (Kumar and Bandara, 2002), SP80-3280 (Rhein et al., 2016) and Q117 (Muchow et al., 1996).The maximum AgNUE in the interspecific hybrids of $S$. spontaneum and clones with E. procerusbase had shown that these species could be the better sources for development nitrogen use efficient varieties in sugarcane. One of the important findings of the study is the early generation hybrids of S.spontaneum $\left(\mathrm{F}_{1}\right)$, E.procerus $\left(\mathrm{BC}_{1}\right)$ had higher AgNUE than the later generation clones. It clearly indicates limited variation in modern cultivars (Co canes) and necessitates utilization of wild relatives in improving NUE in sugarcane. Hawkesford (2017) has also reported a significant and limited variation for NUE and suggested for broader germplasm for improving NUE in wheat. The interspecific hybrids ISH 732, ISH 1875B, ISH 04-941, Erianthus procerus hybrid derivatives GU 1225, GU 12-60, intergeneric hybrid derivatives with E. arundinaceus CYM 12-450, GU 075622,GU 04(72) COE-1, GU 07-2276 and commercial clones Co 95020 and Co 07004 recorded maximum AgNUE could be the potential sources for developing nitrogen efficient varieties in sugarcane (Fig 1). Therefore, these genotypes further considered for utilization in crop improvement programmes for development of elite breeding pools for nitrogen use efficiency.

\section{Future line of works}

Development of nitrogen use efficient responsive sugarcane varieties required to reduce the emission of greenhouse gases, conservation of aquatic ecosystem and cost benefit the farmers. Evaluation of genetically diverse genotypes consisting of improved 'Co' canes and prebreeding material derived from progenies of S. spontaneum, E. arundinaceus, E. procerus and Saccharum-sorghum hybrids under $\mathrm{N}_{0}$ and $\mathrm{N}_{100}$ showed the presence of genetic variability for traits attributing to nitrogen use efficiency. Genotypes were categorized into nitrogen use efficient responsive, nitrogen use non responsive, nitrogen use inefficient responsive and nitrogen use inefficient non responsive genotypes. Therefore, nitrogen use efficient responsive genotypes used for crop improvement programmes through conventional and marker assisted selection. Indian sugarcane varieties and germplasms hall be screened for nitrogen use efficiency and catalogued as nitrogen use efficient and responsiveness. Novel biotechnological approaches such as transcriptome sequencing for gene identification and transgenic approaches for trait improvements. Besides many rhizosphere nitrogen fixing and endogenous microbes $\times$ genotypes shall have been characterized for identification nitrogen use efficient nitrogen responsive genotypes.

\section{Acknowledgement}

Authors are thankful to the Director, ICARSugarcane Breeding Institute, Coimbatore, India for his support and providing necessary facilities to carry out this research work

\section{References}

Bremner JM,Blackmer AM. 1978. Nitrous oxide: Emission from soils during nitrification of fertilizer nitrogen. 
Science 199:295-296.

Burton GW, de vane EH. 1953. Estimating heritability in Tall Fescue (Festuca arundinacea) from replicated clonal material. Agron. J. 45: 481-487.

Carmo JBD, Filoso S.,Luciana C. Zotelli, LC, Neto ES, Pitombo LM, Neto PD, Varga VP, Andrade CA, Gav a KG, Rossetto R, Cantarella HI, Neto AN, Luiz A. Martinelli LA. 2013. Infield greenhouse gas emissions from sugarcane soils in Brazil: effects from synthetic and organic fertilizer application and crop trash accumulation. GCB Bioenergy 5:267280, doi: $\quad 10.1111 / \mathrm{j} .1757-$ 1707.2012.01199.x

Denmead OT, Macdonald BCT, Bryant G, Reilly RJ, Griffith DWT, Stainlay W, White I, Melville MD. 2005. Gaseous nitrogen losses from acid sulfate sugarcane soils on the coastal lowlands. Proc. Aust. Soc. Sugar Cane Technol. 27: 211-219.

Dias MOS, Cunha MP, Jesus CDF, Rocha GJM, Pradella JGC, Carlos E.V. Rossell a, Rubens MacielFilhoAB, Antonio Bonomi,A. 2011. Second generation ethanol in Brazil: Can it compete with electricity production?.Bioresource Technology 102: 8964-8971.

Firestone MK. Davidson EA. 1989. Microbial basis for $\mathrm{NO}$ and $\mathrm{N}_{2} \mathrm{O}$ production and consumption in soil. In: Exchange of traces gases between terrestrial ecosystems and the Atmosphere. Eds M.O. Andre and D.S. Schimel John Wiley and Sons Ltd., Bernhard, Dahlem, Konferenzem. Pp-7-21.

Garnett T, Plett D, Heuer S, Okamoto M. 2015. Genetic approaches to enhancing nitrogen-use efficiency (NUE) in cereals: challenges and future directions. Funct. Plant Biol., 42: 921941
Gascho GJ, Anderson DL, Ozaki HY. 1986. Cultivar Dependent Sugarcane Response to Nitrogen. Agronomy J. 78(6): 1064-1069.

Gomez KA, Gomez A. 1984. Statistical procedure for agricultural research. John Wiley and Sons, Inc., UK. Pp-84118.

Good AG, Shrawat AK, Muench DG. 2004. Can less yield more? Is reducing nutrient input into the environment compatible with maintaining crop production? TRENDS in Plant Sci. 9 (12): 597-605.

Good AG, Beatty PH (2011) Fertilizing Nature: A Tragedy of Excess in the Commons. PLoSBiol 9(8): e1001124. https://doi.org/10.1371/journal.pbio.10 01124

Hawkesford MJ. 2017. Genetic variation in traits for nitrogen use efficiency in wheat. J Exp Bot. 2017 May 1; 68(10):2627-2632. doi: 10.1093/jxb/erx079

Johnson HW, Robinson HF, Comstock RE. 1955. Estimates of genetic and environmental variability in soybeans. Agron. J. 47: 314-318.

Johnson WC, Jackson LE, Ochoa O, Van Wijk R, Peleman J, St.Clair DA, Michelmore RW (2000) Lettuce, a shallow rooted crop, and Lactucaserriola, its wild progenitor, differ at QTL determining root architecture and deep soil water exploitation. TheorAppl Genet 101:1066- 1073

Kanter DR, Zhang X, Mauzerall DL, Malyshev, S and Shevliakova E.2016. The importance of climate change and nitrogen use efficiency for future nitrous oxide emissions from agriculture.Environ. Res. Lett. 11 (2016) 094003,doi:10.1088/17489326/11/9/094003

Kempthorne O. 1957. An Introduction to 
Genetic Statistics. The Iowa State University Press Ames, Iowa, U.S.A.Pp: 224-268.

Knobeloch L, Salna B, Hogan A, Postle J, Anderson H. 2000. Blue Babies and Nitrate-Contaminated Well Water. Environmental Health Perspectives. Environmental Health Perspectives 108(7): 675-678.

Kumara ADS, Bandara DC. 2002. Effect of nitrogen fertilizer on yield and quality parameters of three sugarcane varieties. Tropical Agricultural Research 14:117-127

Lammerts ET, van Bueren, Struik PC. 2017. Diverse concepts of breeding for nitrogen use efficiency. A review. Agron. Sustain. Dev. 37: 50. DOI 10.1007/s13593-017-0457-3.

Le Gouis J, Béghin D, Heumez E, et al., 2000. Genetic differences for nitrogen uptake and nitrogen utilization efficiencies in winter wheat. European Journal of Agronomy, 12:163-173

Leal MRLV, Leite JGDB, Chagas MF, Maia R, Cortez LABC. 2016. Feasibility Assessment of Converting Sugar Mills to Bioenergy Production in Africa. Agriculture $\quad 6, \quad 45: 1-10$ doi:10.3390/agriculture6030045.

Mohanraj K., NairNV. 2014. Biomass potential of novel interspecific hybrids involving improved clones of Saccharum. Industrial Crops and Products, 53: 128-132

Muchow RC, Robertson, MJ, WoodAW. 1996. Growth of sugarcane under high inputconditions in tropical Australia. II. Sucrose accumulation and commercial yield. Field Crops Research, 48 (1): 27-36

Prammanee P, Wood AW. Saffigna PG. 1988. Nitrogen loss from urea applied to sugarcane crop residue. ProcAustSoc Sugar Cane Technol. conference paper $119-124$.
Prasertsak P, FreneyJR,Denmead OT, Saffigna, PG, Prove BG, Reghenzan JR. 2002. Effect of fertilizer placement on nitrogen loss from sugarcane in tropical Queensland. Nutrient Cycling in Agroecosystems 62: 229-239, 2002.

Rhein AFL, Pincelli RP, Arantes MT, Dellabiglia WJ, Kölln OT, Silva MA. 2016. Technological quality and yield of sugarcane grown under nitrogen doses via subsurface drip fertigation $\mathrm{R}$. Bras. Eng. Agríc. Ambiental. 20(3): 209-214.

Roy D. 2000. Plant Breeding Analysis and exploration of variability. Narosa publishing house, New Delhi. Pp: 286289

Siddique KHM, Belford RK, Tennant D (1990) Root-shoot ratios of old and modern, tall and semi-dwarf wheats in a Mediterranean environment. Plant Soil 121:89-98. H

Signor D, Cerri CEP, Conant R. 2013. N2O emissions due to nitrogen fertilizer applications in two regions of sugarcane cultivation in Brazil. Environ. Res. Lett. 8: 1-9. doi:10.1088/1748-9326/8/1/015013.

Sinebo W, RalphG, AntonE. 2004. Genotypic variation for nitrogen use efficiency in Ethiopian barley.Field Crop. Res., 85(1): 43-60

Singh U., LadhaJK, CastilloEG, PunzalanG, Tirol-Padre, DuquezaM.1998. Genotypic variation in nitrogen use efficiency: I. medium-and longduration rice. Field Crop. Res., 58: 3553

Smithers J. 2014. Review of sugarcane trash recovery systems for energy cogeneration in South Africa. Renewable and Sustainable Energy Reviews, 32: 915-925.

Sornpoon W, Bonnet S, Garivait S. 2013. Measurement of Greenhouse Gas Emissions from Sugarcane Plantation 
Soil in Thailand. International Scholarly and Scientific Research \& Innovation 7(12): 862-867.

Souza SP, HortaNogueira LA, Watson HK, Lynd LR, Elmissiry M, Cortez LAB. 2016. Potential of Sugarcane in Modern Energy Development in Southern Africa. Front. Energy Res. 4:39. doi: 10.3389/fenrg.2016.00039

Thorburn PJ, Biggs JS, Palmer J,Meier EA, Verburg K, Skocaj DM. 2017. Prioritizing Crop Management to Increase Nitrogen Use Efficiency in Australian Sugarcane Crops. Front. Plant Sci. 8:1504. doi: 10.3389/fpls.2017.01504

Waclawovsky AJ, Sato PM,.Lembke CG,
Moore PH, Glaucia M. Souza GM. 2010. Sugarcane for bioenergy production: an assessment of yield and regulation of sucrose content. Plant Biotechnology J. 8: 263-276. doi: 10.1111/j.1467-7652.2009.00491.x

Wood AW, Schroeder BL, Dwyer R. 2010. Opportunities for improving the efficiency of use of Nitrogen fertiliser in the Australian sugar industry. ProcAustSoc Sugar Cane Technol. 32: 221-233.

Wrage M, Velthof GL, van Beusi, Oenema O. 2001. Role of nitrifier- denitrifier in the production of nitrous oxide. Soil Biology and Biochemistry 33: 17231732.

\section{How to cite this article:}

Mohanraj, K., T. Manjunatha, C. Mahadevaiah, A. Suganya, S. P. Adhini and Geetha, P. 2020. Genetic Variability for Nitrogen Use Efficiency in Interspecific and Intergeneric Hybrids of Sugarcane. Int.J.Curr.Microbiol.App.Sci. 9(01): 19-30.

doi: https://doi.org/10.20546/ijcmas.2020.901.003 